\title{
CLASSIFICATION OF APPLE DEFECTED FRUITS USING COLOR IMAGE ANALYSIS TECHNIQUE
}

\section{A. A. Abd El-Rahman ${ }^{1}$ \\ ABSTRACT}

Image analysis algorithm was developed to provide the classification parameters for defect of yellow apple fruits. The objectives of this work are: 1) To use and test an image processing system which could classify defects on apple surfaces based on color analysis, and 2) Extraction of values of Red, Green and Blue (RGB) coordinates and color properties of Hue, Saturation, and Intensity (HSI) from the infected area. Experimental setup of color analysis was used for taking an image for each apple sample to find and identify apple defect. The results indicated the following points: (1) The value of red color component was decreased (162 - 73.4), (170.4 - 104.4), (210.8 - 98.4), and (202.6 - 113.1 values), and the value of green color component was decreased (148.6 73.5), (122.2 - 61.2), (181 - 62.4), and (180.1 - 90.3 values). Meanwhile, the blue color component value changed a little, it is ranged (61.6-61.9), (61.1-63.4), (61.4- 62.0), and (61.6- 62.7 values), for color, fungi, bruises and operation defects (which classified into four subclasses of each defect), respectively., (2) The value of red color component was decreased (134.6 - 84.4), (203 - 186.6), (143.8 - 98.4), and (202.8 - 174.9 values), and the value of green color component was decreased (100 75.2), (131.4 - 118.), (115.4 - 61.4), and (184.8 - 154.6 values), respectively. Meanwhile, the blue color component value changed a little, it is ranged (62.1- 66.8), (61.6- 62.0), (61.4- 63.4), and (62.4- 62.6 values) for insect, scare, mechanical and russet defects of apple fruit (which classified into three subclasses of each defect), respectively., (3) The value of color component $(R, G$ and $B)$ and color properties $(H, S$ and I) were very important to classify defect of apple fruit., (4) Using of image analysis method in estimation of apple defects, to develop of a sorting system for sorting of apples fruit based on color analysis., and (5) Establishment measuring standard for defects of apple fruits according to image processing technique.

1- Senior Res., Agr. Eng. Res. Inst., Agr. Res. Center, Cairo, Egypt. 


\section{INTRODUCTION}

utomatic classification of agricultural products is a necessity for
agricultural marketing to increase the speed and minimize the
miss-classifications.

Heinemann et al. (1995) used the hue $(\mathrm{H})$ to discriminate russet. It was a global approach, since the mean hue on the apple was computed. A discriminant function sorted the apple as accepted or rejected. The accuracy reached 82.5\%, which is poor compared with European standards.

Leemans et al. (1999) showed how the information enclosed in a colour image of a bi-colour apple can be used to segment defects. The colour frequency distributions of the healthy tissue and of the defects were used to estimate the probability distribution of each class. The results showed that most defects, namely: bitter pit, fungi attack, scar tissue, frost damages, bruises, insect attack and scab, are segmented.

Schaare and Fraser (2000) mentioned that the fruits are only classified simply according to size and weight. The defects of lower levels classification and poor timeliness would influence other aspects such as ripening, packaging and cooling directly. Fruit quality detection is an important aspect of fruit commercialization, and the fruit appearance is an important index of detecting fruit quality.

Toth and Aach (2001) said that a stem segmentation algorithm based on morphological operations is proposed firstly, before detecting fruit surface defects, remove the interference of existing stems. Next, the fruit surface defects are detected based on phase of Fourier transform attention model. Finally, for the fruit images of existing surface defects, the color and texture features of defect part are extracted and classified based on support vector machine, and achieve defect fruits classification.

Penman (2002) explained that in oranges, peaches and apples there is an interest in detecting long stems in order to avoid damage to other fruit, or because their absence could imply a quality loss. Several solutions have been proposed to determine the position of the stem, such as: the use of structured lighting to detect concavities in apples; colour segmentation 
techniques to differentiate the calyx and stem in citrus fruits; or the study of light reflection in apples.

Bulanon et al. (2002) mentioned that in most cases, navigation of robot was carried out using a machine vision based system. Also, they used RGB model for recognition of cotton. They used the R-B feature for this purpose. The $\mathrm{R} /(\mathrm{R}+\mathrm{G}+\mathrm{B})$ feature was used for recognition of orange fruits on the tree. An algorithm for the automatic recognition of Fuji apples on the tree was developed for a robotic harvesting system.

Kleynen et al. (2003) presented a method based on quadratic discriminant analysis to select the best filters for detecting a wide range of defects in 'Jonagold' apple fruit using a multi-spectral vision system. Reflectance spectra of damaged and sound tissue were recorded using a visible/NIR spectrometer. Analyzed defects consisted of scald, hail damage (with and without skin perforation), limb rubs, russets, scab tissue, frost damage, rot, visible flesh damage and recent bruises.

Leemans and Destain (2004) decided that the bad part of fruit surface can be called as defect, which is one of the important qualities of fruits, the main problems and difficulties of detecting agricultural products surface defects by applying image processing technology are shown as follows:(1) The influence of light reflection because of different curvatures on fruit surface, and (2) The stems are misjudged as defects.

Throop et al. (2005) stated the visual inspection of apples with respect to size and color by machine vision is already automated in the industry. However, detection of defects is still problematic due to high variance of defect types, presence of stem/calyx concavities and natural variability of skin color. Majority of the works performing defect segmentation of apples used simple thresholding .

Lorestani et al. (2006) mentioned that the quality grading includes outer parameters (size, color intensity, color homogeneity, bruises, shape, stem identification surface texture and mass), inner parameters (sweetness, acidity or inner diseases) and freshness. Both outer and inner quality information can be collected by an automatic grading system in a factory, but machine vision is more effective for measuring outer parameters. 
Bock et al. (2008) studied on severity of citrus canker visually and with image analysis technique. They used image processing technique to classify infected fruits based on features of Red, Green and Blue (RGB). They reported that color analysis indicated distinct color differences between infected and healthy fruits.

Khojastehnazhand et al. (2009) proposed a multi-product grading system for agricultural products. Recently, they developed an image processing technique for estimating citrus fruits physical attributes including diameters, volume, mass and surface area.

Arman et al. (2011) showed a segmentation algorithm that was developed for guidance of a robot arm to pick the ripen tomato using a machine vision system. The developed algorithm works in two steps: (1) removing the background in RGB color space and then extract the ripen tomato using combination of RGB, HSI, and YIQ spaces and (2) localizing the ripen tomato using morphological features of image. According to the results, the total accuracy of proposed algorithm was $96.36 \%$.

Panli (2012) mentioned that in order to improve the commercialization level of post-natal fruit, classify fruits effectively according to advantages and disadvantages of fruits, a fruit surface defect detection and classification algorithm based on attention model is proposed. Finally, the color and texture features of fruits defective part are extracted and classified by support vector machine.

Leila et al. (2012) mentioned that to estimate the severity of apple blue mold disease by chemo-biological approach, using RGB channels; an experiment was done using two antagonistic yeasts. Extraction of statistical moments of RGB channels in infected area showed that Red standard deviation was the most important feature which separated the A and B groups with accuracy of 80 and $100 \%$, respectively.

The objectives of this work are:

1- To develop and test an image processing system which could classify defects on apple surfaces based on color analysis defects of apple fruits, 2- Extraction of values of Red, Green and Blue (RGB) coordinates and 
color properties of Hue, Saturation, and Intensity (HIS) from the infected area, and 3) Possibility of using computer vision for the quality inspection of apples fruits.

\section{MATERIAL AND METHODS}

The experiments were carried out at the Laboratory of Laser Application in the Agricultural Engineering at National Institute of Laser Enhanced Science (NILES), Cairo University, Egypt. The experiments and measurements for the color properties of apple fruit defects were carried out according to the following procedures:

\section{Sample preparation:}

A random sample of apple was obtained from the commercial local market. After cleaning and washing the apple fruits, the samples were divided into different defect shape. The defect shape of apple fruits were sorted manually according to surface defect by eyes. Sample of one hundred of apple fruit was investigated.

Color analysis setup: The experimental setup was adjusted at incident angle equal to reflected angle $\left(45^{\circ}\right)$ to obtain high reflections of color of each pixel in image for apple fruit defect and to establish criteria for identifying color properties of apple fruit defects. The schematic and experimental setup is shown in Figs. (1and 2).

Digital luxmeter: A digital luxmeter with high accuracy and sensitivity was used. Digital luxmeter had range of 0-50,000 Lux

Personal computer: A personal computer was connected to the digital camera to transfer image for image processing. In every image, the fruit defect area was separated, the fruit width and height (an image of $640 X 480$ pixels), type of image was true color (24 bit), with resolution of 118 pixels $/ \mathrm{cm}$. Four images were acquired for each apple fruit using the digital camera, and then this image was transmitted to computer software for image analysis. The average color components (RGB) and color properties (HSI) of the image were determined.

Digital camera: Digital camera was used to take a photo image for each apple fruit sample; each fruit had four images, from up and down and 
sides. For position adjustment of image, camera stand was used in order to fix the distance between digital camera and sample of apple fruit (26 $\mathrm{cm}$ ), and intensity of light (530 lux). Specification of digital camera and its stand is summarized in Table (1).

Table (1): Specifications of the digital camera and its stand.

\begin{tabular}{|l|l|}
\hline Item & Specification \\
\hline Digital camera: & \\
Model & Power Shot G2, Cannon \\
Source of manufacture & Japan \\
Resolution, megapixel & 4.0 \\
LCD Monitor, inch & 1.8, polycrystalline silicon TFT color. \\
Shutter speeds, s & $1 / 1000$ to 15 \\
Image sensor & Approx. 4- million - pixel/1/1.8 inch CCD \\
Power source & Rechargeable lithium-Ion battery \\
Camera stand: & \\
Model & Hama Reporo \\
Source of manufacture & Germany \\
No. of lamp & 4 \\
Lamp power, W & 100 \\
Power supply electricity, Volt & 220 \\
Length of stand, cm & 73 \\
Light incident angle, degrees. & 45 \\
\hline
\end{tabular}

Color analysis: Algorithm of fruit vision is based on RGB color model (Leemans et al., 1998). When color is presented with R, G and B, the amount of information is measured. However, RGB system is sensitive to lighting, (Red, Green, and Blue color components coordinator from 0 255). Another color model is HSI (Hue is from 0 to $360^{\circ}$, Saturation is from 0 to 100 value and Intensity is from 0 to 100 value). 


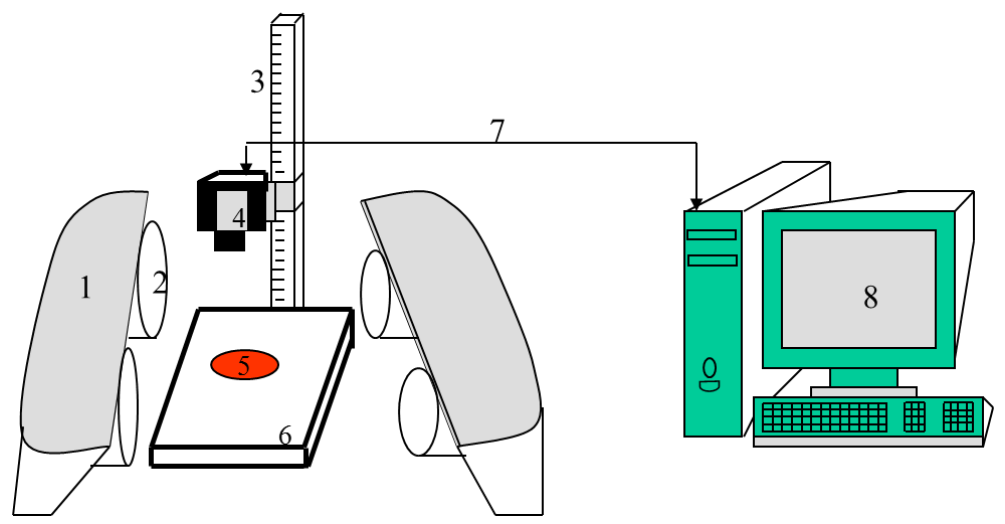

1 - Cover; 2- Lamp; 3 - Stand ; 4- Camera; 5 - Apple fruit ample; 6- Stand basis; 7 -Electric wire; and 8- Personal computer.

Fig. 1: Schematic diagram setup for measuring color properties of apple fruit defects.

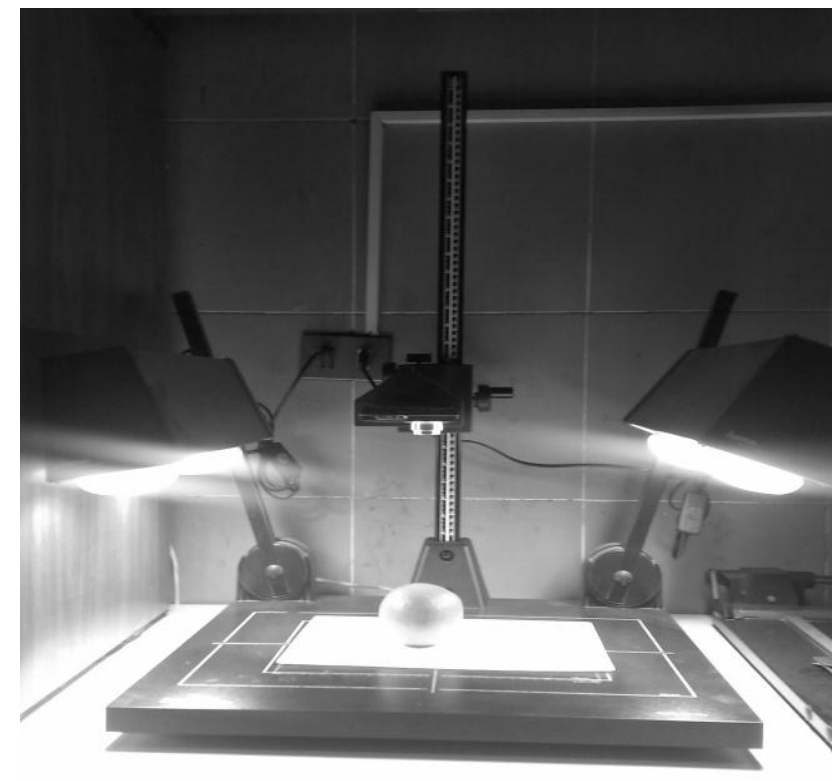

Fig. 2: Experimental setup photo for measuring color properties of apple fruit defects. 


\section{RESULTS AND DISCUSSION}

The defects of apple fruits were classified into eight classes according to defect types namely; color, fungi, bruises, insect, scare, mechanical, and operation defects. Each defect type was divided into subclasses defect according to infection using color analysis, based on value of color component value of color apple fruit [Red, Green, and Blue value (RGB)] and description of this apple defect using color properties [Hue degree, Saturation value, and intensity value (HSI)]. The apple defects were classified according to different color component values (RGB) of apple defects, comparison in color component value of control sample which was $\mathrm{R}=183.6, \mathrm{G}=172$, and $\mathrm{B}=62.4$ value, and its color properties value (HIS) was $\mathrm{H}=53.2^{\mathrm{O}}, \mathrm{S}=65.9$, and $\mathrm{I}=72$ values.

Fig. 3 shows the color component values of apple color defects. It is noticed that the red color component values for color defect of apple fruit were 162, 145, 138, and 73.4 values. Meanwhile, the green color component values were 148.6, 138.9, 115.6, and 73.5 values for light red area, green area, brown, and dark green of color area defect, respectively. However, the blue color component value changed a little from 61.6 to 61.9 values for the same four subclasses color defect of apple.

In the classification of apple color defects, it was found that the value of red color component decreased from 162 to 73.4 values, and the value of green color component decreased from 148.6 to 73.5 values. Meanwhile, the blue color component value changed from 61.6 to 61.9 values for color defect of apple fruits.

Fig. 4 shows the color property values of apple color defects. It is noticed that the hue, saturation and intensity (HSI) values for color defect of apple fruit were $\left(62.4^{\circ}, 62.0\right.$, and 63.4 value), $\left(46.4^{\circ}, 58.0\right.$, and 58.0 value), $\left(60.6^{\circ}, 55.0\right.$, and 54.2 value $)$, and $\left(41.8^{\circ}, 50.0\right.$, and 28.9 value) for light red area, green area, brown, and dark green of color area defect, respectively.

Fig. 5 shows the color component values of apple fungi defects, it is noticed that the red color component values for fungi defect of apple fruit were 170.4, 153.9, 128.5, 104.4 values. Meanwhile, the green color component values were 122.2, 115.1, 92.3, and 61.2 values for very light red area, light red, red, and dark red of fungi area defect, respectively. 
However, the blue color component value changed a little from 61.1 to 63.4 values for same four subclasses fungi area defect of apple fruits.

In the classification of apple fungi defects, it was found that the value of red color component decreased from 170.4 to 104.4 values, and the value of green color component decreased from 122.2 to 61.2 values. Meanwhile, the blue color component value changed from 61.1 to 63.4 values for fungi defect of apple fruits.

Fig. 6 shows the color property values of apple fungi defects. It is noticed that the hue, saturation and intensity (HSI) values for fungi defect of apple fruit were $\left(34.3^{\circ}, 63.4\right.$, and 66.8 value), $\left(33.1^{\circ}, 60.7\right.$, and 60.3 value), $\left(26.0^{\circ}, 50.4\right.$, and 50.4 value $)$, and $\left(12.0^{\circ}, 41.5\right.$, and 40.8 value $)$ for very light red area, light red, red, and dark red of fungi area defect, respectively.

Fig. 7 shows the color component values of apple bruises defects. It is noticed that the red color component values for bruises defect of apple fruit were 210.8, 144.3, 133.6, and 98.4 values. Meanwhile, the green color component values were 181, 113, 102, 62.4 value for very light, light, medium, and hard infection of bruises area defect, respectively. However, the blue color component value changed a little from 61.4 to 62.0 values for the same four subclasses bruises defect of apple fruits.

In the classifications of apple bruises defects, it was found that the value of red color component decreased from 210.8 to 98.4 values, and the value of green color component decreased from 181 to 62.4 values. Meanwhile, the blue color component value changed from 61.4 to 62.0 values for bruises defect of apple fruits.

Fig. 8 shows the color property values of apple bruises defects. It is noticed that the hue, saturation and intensity (HSI) values for bruises defect of apple fruit were $\left(47^{\circ}, 70.8\right.$, and 82.7 value), $\left(37^{\circ}, 57.0\right.$, and 56.7 value), $\left(33.2^{\circ}, 53.4\right.$, and 52.4 value), and (13.0 ${ }^{\circ}, 37.6$, and 38.6 value) for very light red area, light red, red, and dark red of bruises area defect, respectively.

Fig. 9 shows the color component values of apple insect defects. It is noticed that the red color component value for insect defect of apple fruit were 134.6, 99.2, and 84.8 values. 


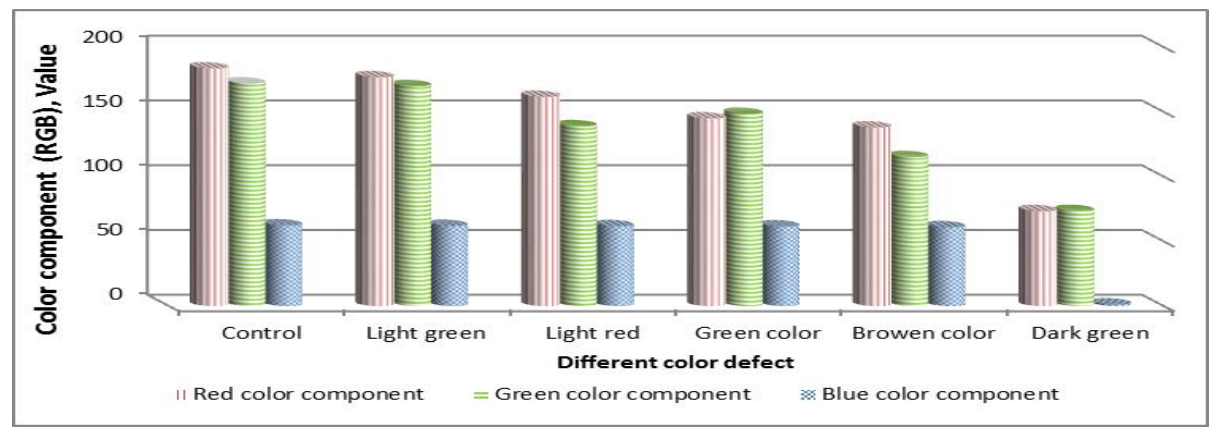

Fig. (3) : Color component of different color defects of apple fruits.

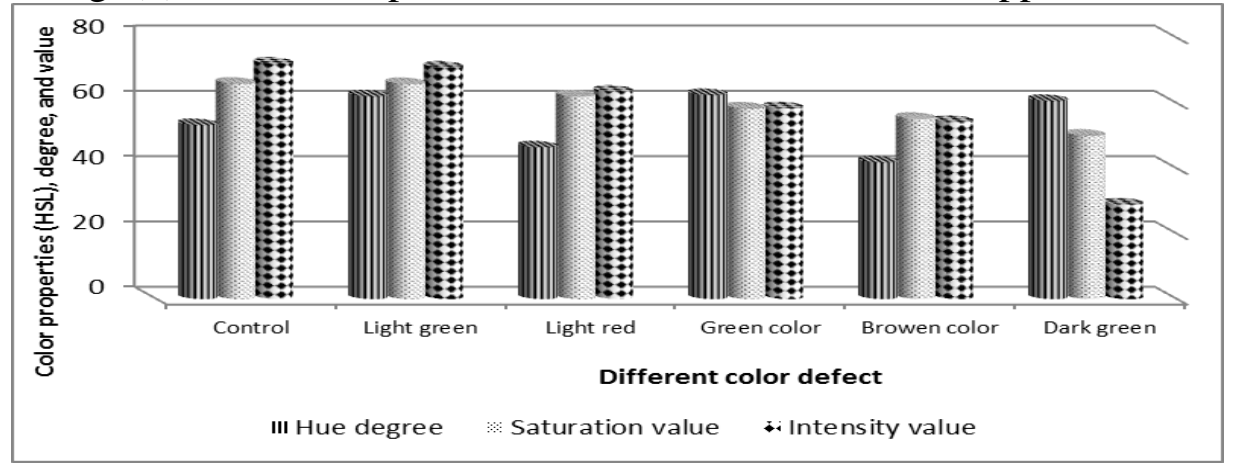

Fig. (4) : Color properties of different color defects of apple fruits.

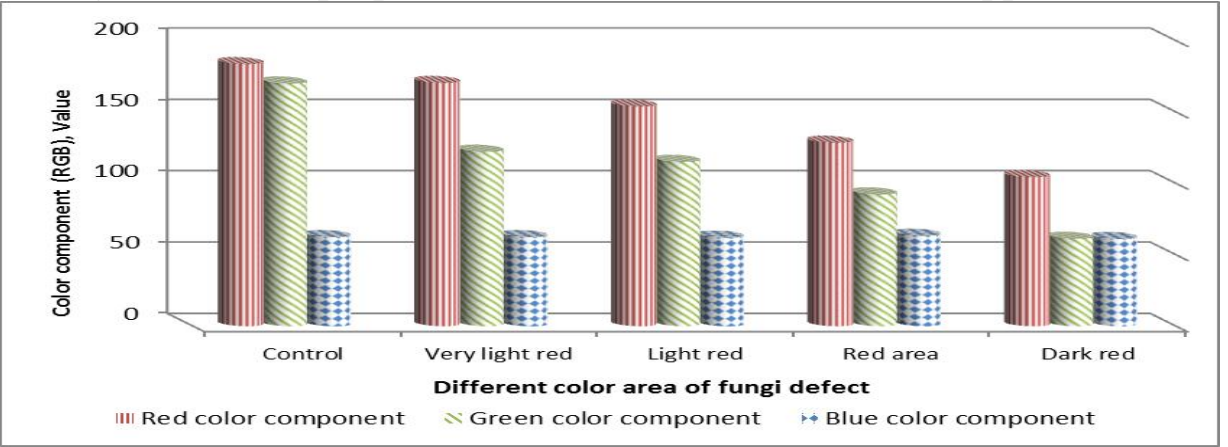

Fig. (5) : Color component of different fungi defects of apple fruits.

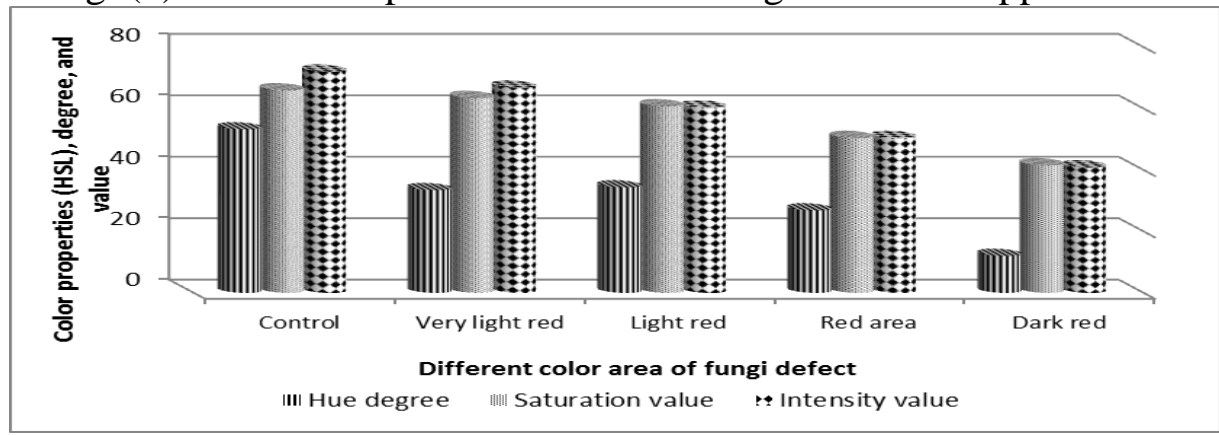

Fig. (6) : Color properties of different fungi defects of apple fruits. 
Meanwhile, the green color component values were 100, 86.4, and 75.2 values for light, hard and very hard of insect area defect, respectively.

However, the blue color component value changed a little from 62.1 to 66.8 values for the same three subclasses insect defect of apple.

In the classification of apple insect defects, it was found that the value of red color component decreased from 134.6 to 84.4 values, and the value of green color component decreased from 100 to 75.2 values. Meanwhile, the blue color component value changed a little from 62.1 to 66.8 values for insect defect of apple fruits.

Fig. 10 shows the color property values of apple insect defects. It is noticed that the hue, saturation and intensity (HSI) values for insect defect of apple fruit were $\left(31.9^{\circ}, 53.7\right.$, and 52.7 value $),\left(36.2^{\circ}, 32.6\right.$, and 39.0 value), and $\left(33.6^{\circ}, 26.0\right.$, and 33.5 value) for light, hard and very hard of insect area defect, respectively.

Fig. 11 shows the color component values of apple mechanical defects. It is noticed that the red color component value for mechanical defect of apple fruit were 143.8, 112.5, and 98.4 values. Meanwhile, the green color component values were 115.4, 64.0, and 61.4 values for light, medium and hard of mechanical area defect, respectively. But, the blue color component value was changed a little from 61.4 to 63.4 values for the same three subclasses mechanical defect of apple fruits.

In the classification of apple mechanical defects, it was found that the value of red color component decreased from 143.8 to 98.4 values, and the value of green color component decreased from 115.4 to 61.4 values. Meanwhile, the blue color component values of mechanical defect changed a little from 61.4 to 63.4 values for mechanical defect of apple fruits.

Fig. 12 shows the color property values of apple mechanical defects. It is noticed that the hue, saturation and intensity (HSI) values for mechanical defect of apple fruit were $\left(39.2^{\circ}, 57.6\right.$, and 56.6 value $),\left(20.0^{\circ}, 45.5\right.$, and 44.3 value), and $\left(12.0^{\circ}, 37.6\right.$, and 38.6 value) for light, medium and hard of mechanical area defect, respectively. 


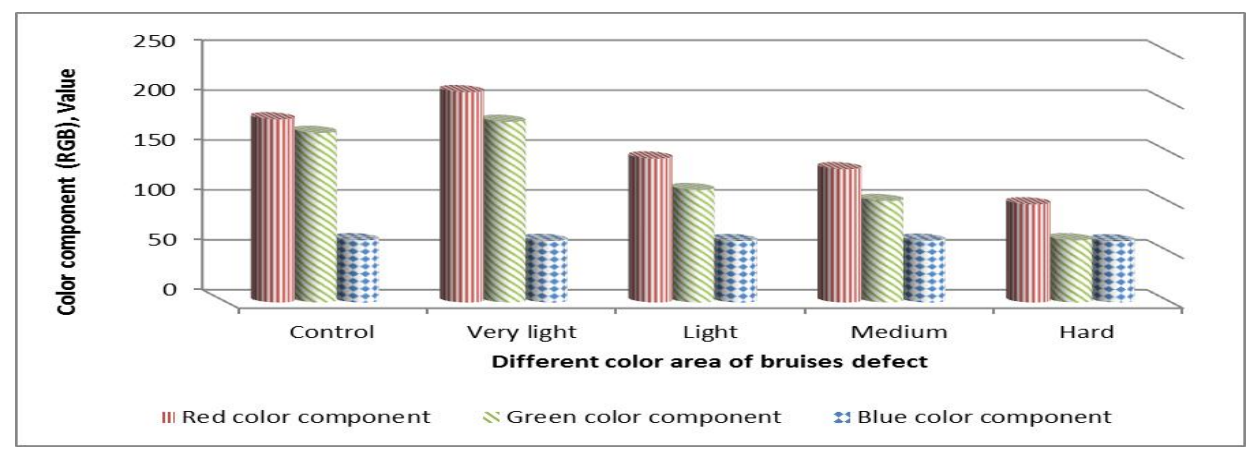

Fig. (7) : Color component of different bruises defects of apple fruits.

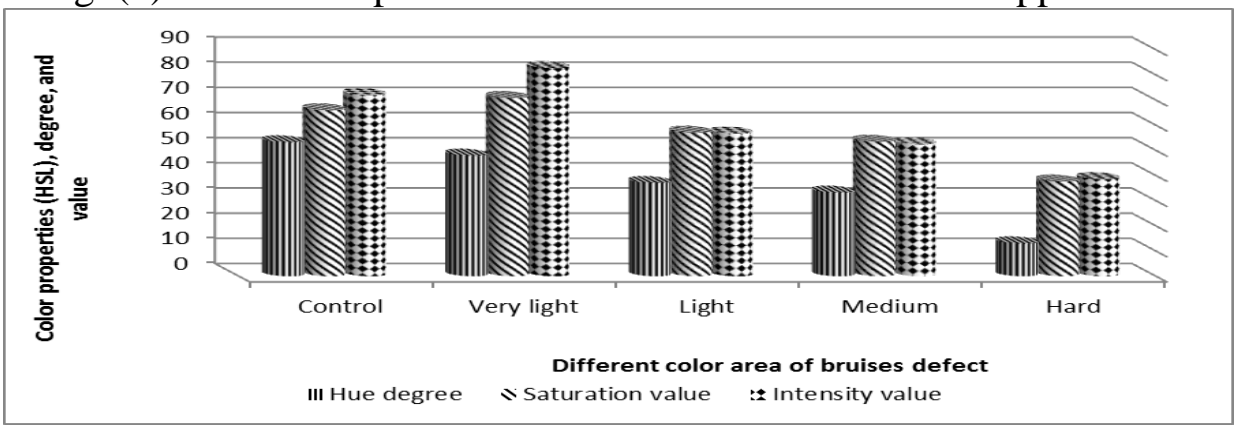

Fig. (8) : Color properties of different bruises defects of apple fruits.

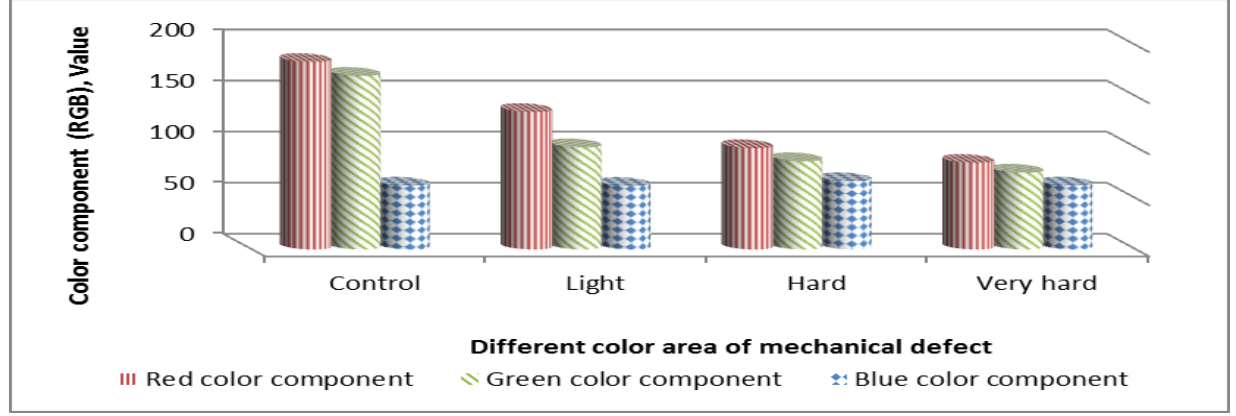

Fig. (9) : Color component of different insect defects of apple fruits.

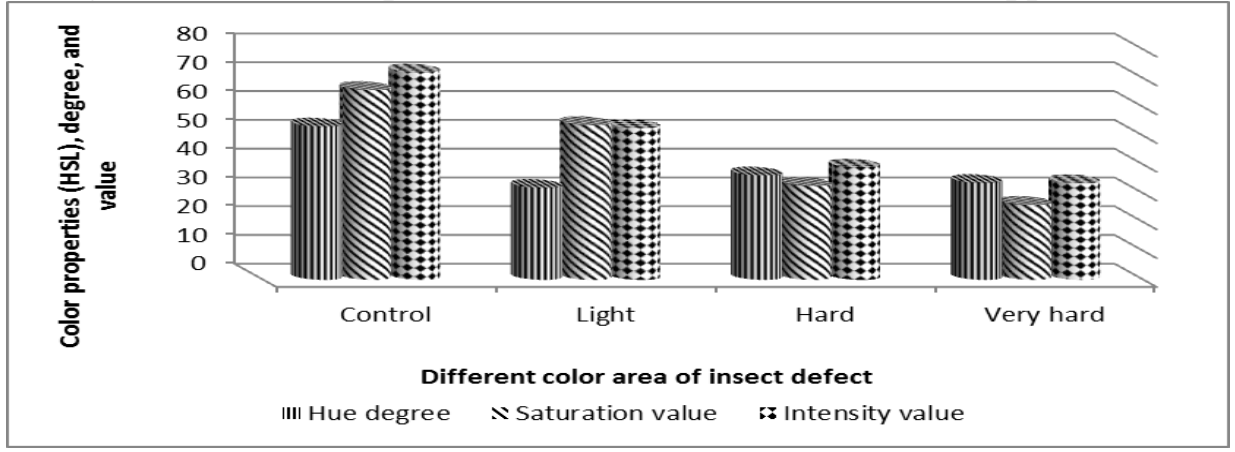

Fig. (10) : Color properties of different insect defects of apple fruits. 
Fig. 13 shows the color component values of apple scare defects. It is noticed that the red color component value for scare defect of apple fruit were 203, 188.8, and 186.6 values. Meanwhile, the green color component values were $131.4,114.5$, and 118.2 values for light red, red and dark red of scare area defect, respectively. However, the blue color component value changed a little from 61.6 to 62.0 values for the same three subclasses scare defect of apple.

In the classification of apple scare defects, it found that the value of red color component decreased from 203 to 186.6 values, and the value of green color component decreased from 131.4 to 118.2 values. Meanwhile, the blue color component value changed a little from 61.6 to 62.0 values for scare defect of apple fruits.

Fig. 14 shows the color property values of apple scare defects, it noticed that the hue, saturation and intensity (HSI) values for scare defect of apple fruit were $\left(30.0^{\circ}, 69.6\right.$, and 79.0 value $),\left(24.8^{\circ}, 67.2\right.$, and 74.1 value), and $\left(27.2^{\circ}, 66.5\right.$, and 73.2 value) for light red, red and dark red of scare area defect, respectively.

Fig. 15 shows the color component values of apple russet defects. It is noticed that the red color component value for mechanical defect of apple fruit were 202.8, 183.4, and 174.9 values. Meanwhile, the green color component values were $184.8,154.6$, and 154.6 values for light watery, medium watery and hard watery of russet area defect, respectively. However, the blue color component value changed a little from 62.4 to 62.6 values for the same three subclasses russet area defect of apple fruits.

In the classification of apple russet defects, it was found that the value of red color component decreased from 202.8 to 174.9 values, and the value of green color component decreased from 184.8 to 154.6 values. Meanwhile, the blue color component value changed a little from 62.4 to 62.6 values for russet area defect of apple fruits.

Fig. 16 shows the color property values of apple russet defects. It is noticed that the hue, saturation and intensity (HSI) values for russet defect of apple fruit were $\left(52.3^{\circ}, 69.3\right.$, and 79.5 value $),\left(45.6^{\circ}, 66.0\right.$, and 72.2 value), and $\left(49.2^{\circ}, 64.1\right.$, and 68.6 value) for light watery, medium watery and hard watery of russet area defect, respectively. 


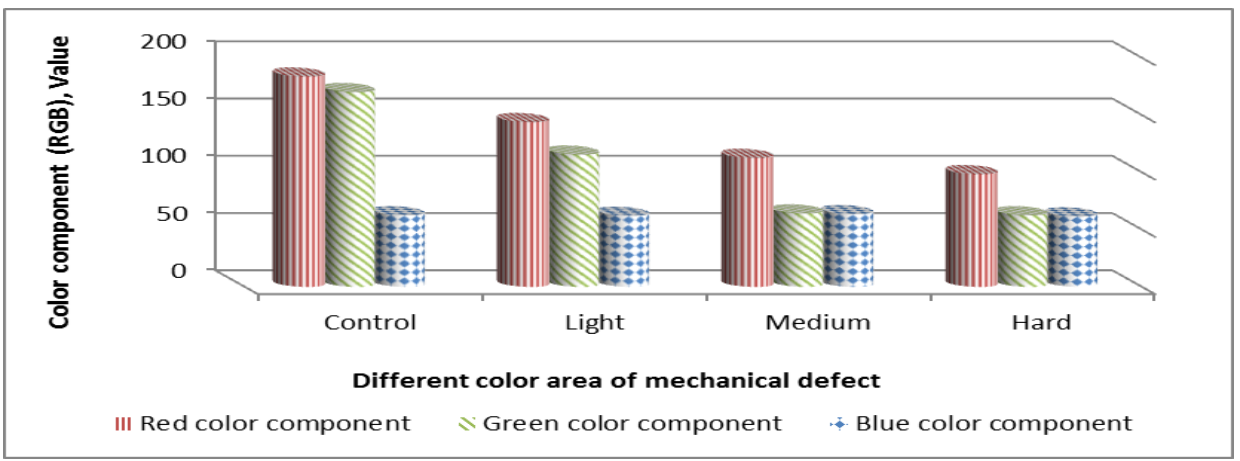

Fig. (11) : Color component of different mechanical defects of apple fruits.

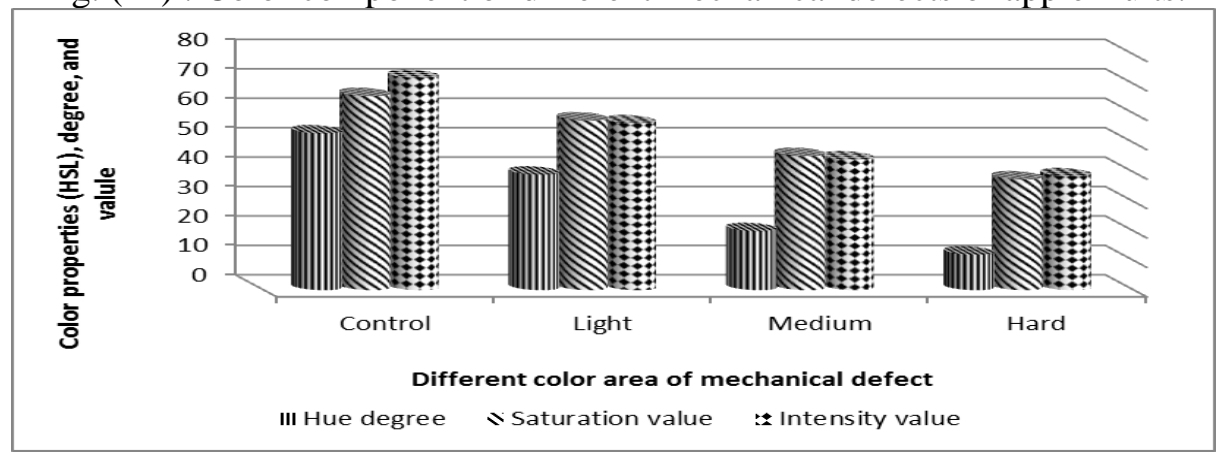

Fig. (12) : Color properties of different mechanical defects of apple fruits.

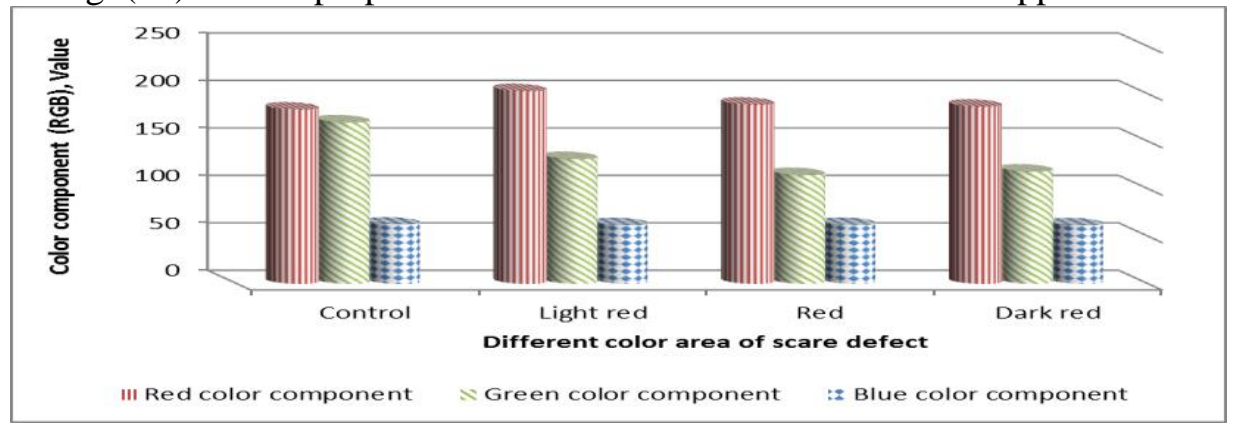

Fig. (13) : Color component of different scare defects of apple fruits.

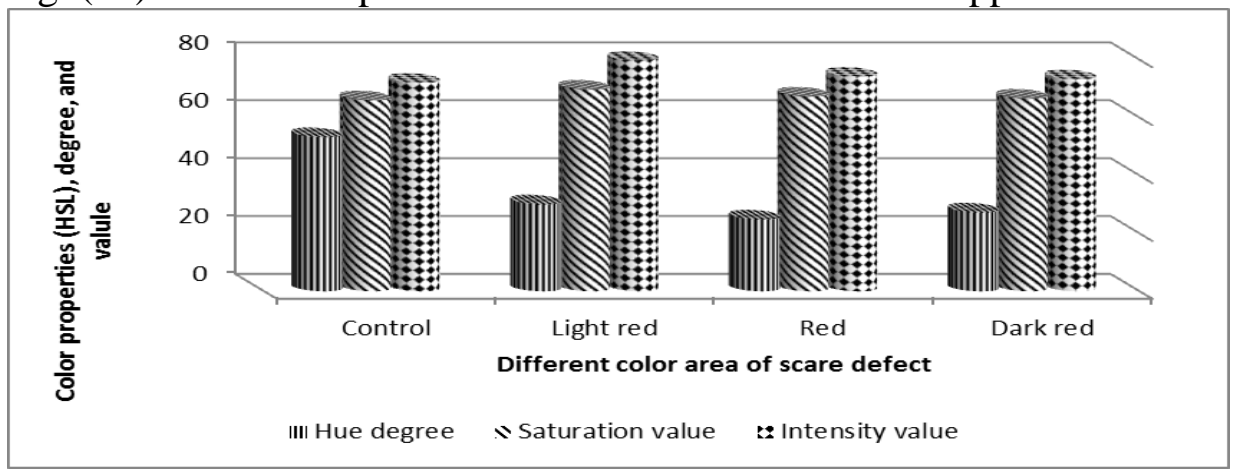

Fig. (14) : Color properties of different scare defects of apple fruits. 
Fig. 17 shows the color component values of apple operating defects. It is noticed that the red color component values were 202.6, 194.6, 153.8, and 113.1 values. Meanwhile, the green color component values for operating defect of apple fruit were 180.1, 177.2, 108.0, 90.3 value for cooling, storage, sun, and stem presence of operating defect, respectively. But, the blue color component value changed a little from 61.6 to 62.7 values for the same four subclasses operating defect of apple.

In the classification of apple operating defects, it was found that the value of red color component decreased from 202.6 to 113.1 values, and the value of green color decreased from 180.1 to 90.3 values. Meanwhile, the blue color component value changed a little from 61.6 to 62.7 values for operating defect of apple fruits.

Fig. 18 shows the color property values of apple operating defects. It is noticed that the hue, saturation and intensity (HSI) values for operating defect of apple fruit were $\left(50.4^{\circ}, 69.0\right.$, and 79.4 value $),\left(51.8^{\circ}, 68.4\right.$, and 76.0 value), $\left(30.2^{\circ}, 59.7\right.$, and 60.3 value), and (31.1 ${ }^{\circ}, 45.6$, and 44.9 value) for cooling, storage, sun, and stem presence of operating area defect, respectively.

From the previous results, it is seen that the red and green color components of color, fungi, bruises, insect and mechanical apple defect fruits were lower than both of red and green color component values of control sample. Meanwhile, blue color component values changed a little. Meanwhile, Red color component value of apple scare defected fruits was higher than red color component values of control sample. Meanwhile, green color component value of apple scare defected fruits was lower than green color component value of control sample. However, blue color component values changed a little. For red and green color components values of apple russet defected fruits in case of light watery were higher than red and green color component values of control sample. Meanwhile, red and green color components values of apple russet defect fruits in case of medium and hard watery were lower than red and green color component value of control sample. However, blue color component values changed a little 


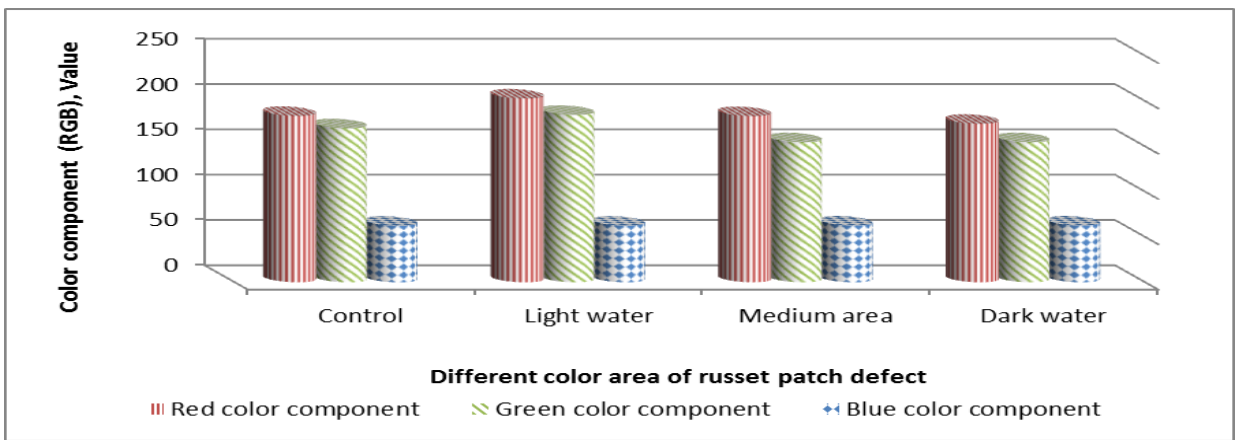

Fig. (15) : Color component of different russet patch defects of apple fruits.

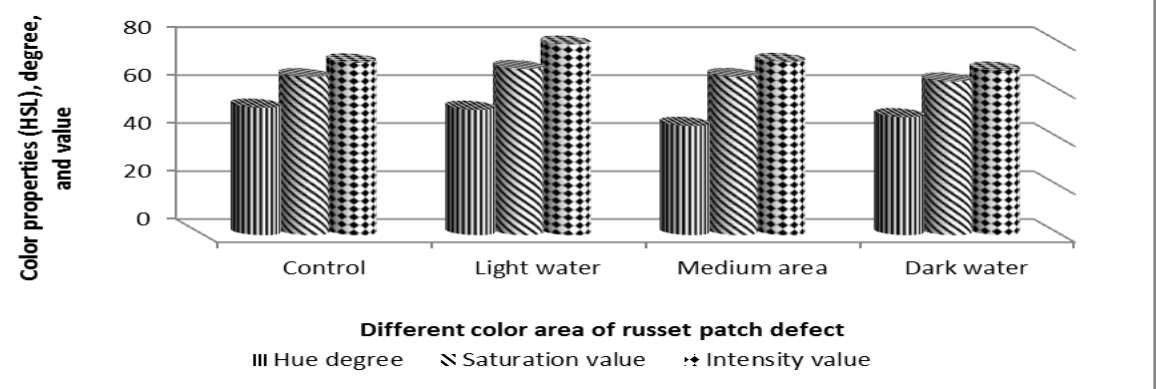

Fig. (16) : Color properties of different russet patch defects of apple fruits.

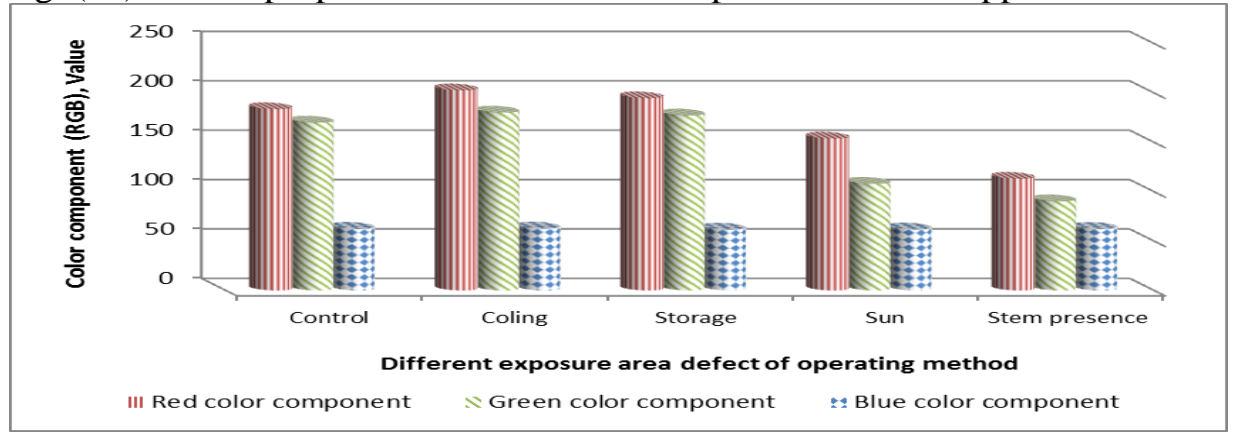

Fig. (17) : Color component of different exposure area defect of operating methods for apple fruits.

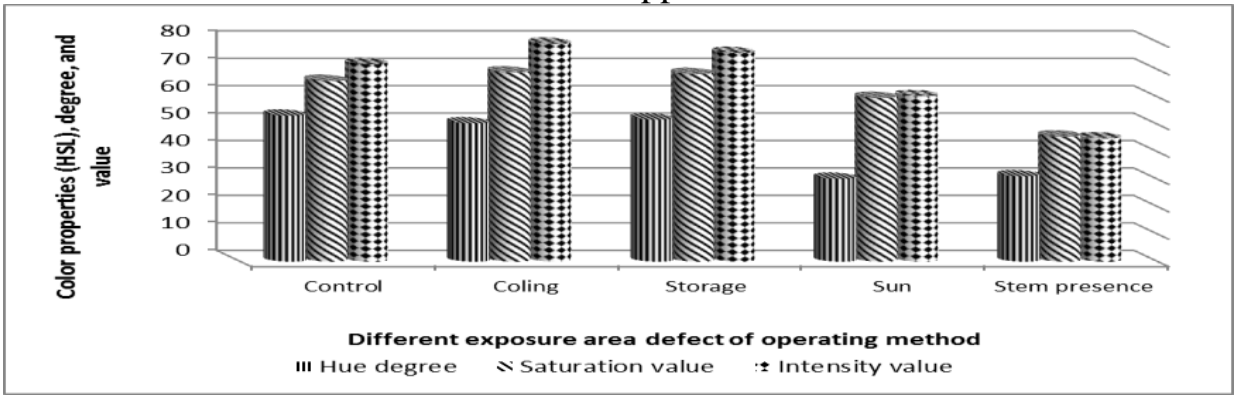

Fig. (18) : Color properties of different exposure area defect of operating methods for apple fruits. 
For red and green color components values of apple operation defected fruits in cooling and storage cases were higher than red and green color components values of control sample. Meanwhile, red and green color components values of apple operation defected fruits in sun exposure and stem presence cases were lower than red and green color components values of control sample. However, blue color component values changed a little.

\section{CONCLUSION}

(1) Color component values (RGB) of control sample was $\mathrm{R}=183.6$, G $=172$, and $\mathrm{B}=62.4$ values, and its color analysis value $(\mathrm{HSI})$ was $\mathrm{H}=$ $53.2^{\mathrm{O}}, \mathrm{S}=65.9$, and 72 value., (2) The value of red color component was decreased (162 - 73.4), (170.4 - 104.4), (210.8 - 98.4), and (202.6 113.1 values), and the value of green color component was decreased (148.6 - 73.5), (122.2 - 61.2), (181 - 62.4), and (180.1 - 90.3 values). Meanwhile, the blue color component value changed a little, it is ranged (61.6- 61.9), (61.1- 63.4), (61.4- 62.0), and (61.6- 62.7 values), for color, fungi, bruises and operation defects (which classified into four subclasses of each defect), respectively., (3) The value of red color component was decreased (134.6 - 84.4), (203 - 186.6), (143.8 - 98.4), and (202.8 - 174.9 values), and the value of green color component was decreased (100 75.2), (131.4 - 118.0), (115.4 - 61.4), and (184.8 - 154.6 values), respectively. Meanwhile, the blue color component value changed a little, it is ranged (62.1- 66.8), (61.6- 62.0), (61.4- 63.4), and (62.4- 62.6 values) for insect, scare, mechanical and russet defects of apple fruit (which classified into three subclasses of each defect), respectively., (4) The value of color component (R,G and B) and color properties (H, S and I) were very important to classify defect of apple fruit., and (4) Using of image analysis method in classification of apple defects, to develop of a sorting system for sorting of apples fruit based on color analysis., (5) So, the algorithm can be easily used for grading/sorting different agricultural products (grains, fruits and vegetables)., and (6) Establishment measuring standard for defects of apple fruits, the values were decreased in color, fungi, insect, and mechanical defects, while the values were increased in bruises, operation, scare, and russet defect with compression sound fruits. 
PROCESS ENGINEERING

\section{REFERENCES}

Arman A., A. M. Motlagh, K.Mollazade and R.F.Teimourlou (2011 ). Recognition and localization of ripen tomato based on machine vision. Dep. of Agric. Mach. Eng., Agric. Fac., Urmia univ. AJCS 5(10):1144-1149.

Bock C.H., P.E. Parker, A.Z. Cook and T.R. Gottwald (2008). Characteristics of the perception of different severity measures of citrus canker and the relationships between the various symptom types. Plant Dis. 92: 927-939.

Bulanon D.M., T. Kataoka, Y. Ota and T. Hiroma (2002). A segmentation algorithm for the automatic recognition of fuji apples at Harvest. Biosist. Eng. 83(4):405-412.

Heinemann P.H., Z.A.Varghese, C.T.Morrow, H.J. Sommer, R.M.Crassweller (1995). Machine vision inspection of Golden Delicious apples. Appl. Eng. Agric. ASAE 11 (6):901-906.

Khojastehnazhand M., M. Omid and A. Tabatabaeefar (2009). Determination of orange volume and surface area using image processing technique. Int. Agrophy. 23: 237-242.

Kleynen, O., V. Leemans, and M. F. Destain (2003). Selection of the most efficient wavelenth bands for 'Jonagold' apple sorting. In: Postharvest Bio. and Tech., 30: 221-232.

Leemans V, Magein H. and Destain MF (1998). Defects segmentation on 'Golden Delicious' apples by using color machine vision. Comput. and Electron. in Agric., 20: 117-130.

Leemans V. and Destain M.-F. (2004). A real-time grading method of apples based on features extracted from defects. In: J. of Food Eng., 61:83-89.

Leila F., R.E.Hasan; M.T.Hadis, S. Navazolah and A. Heshmatolah (2012). Computer-based recognition of severity of apple blue mould using RGB components. Comput. Eng. Dep., Sharif Un. Techn., Tehran, Iran. Int. Res. J. of Appl. and Basic Sc. 3 (1):39-45.

Lorestani A.N., M. Omid, S.B. Shooraki, A.M. Borghei and A. Tabatabaeefar (2006). Design and evaluation of a Fuzzy Logic 
based decision support system for grading of Golden Delicious apples. Int. J. Agric. Biol. 8(4): 440-444.

Panli, H. E. (2012). Fruit surface defects detection and classification based on attention model. Sch. Info. Eng., Shenyang Univ., Shenyang, China. J. of Comput. Info. Sys. 8 (10): 4233-4240.

Penman, D.W. (2002). Determination of stem and calyx location on apples using automatic visual inspection. Comput. and Elect. in Agric., 33: 7-18

Schaare, P. N. and D. G. Fraser. (2000). Comparison of reflectance, Interactance and transmission modes of visible near infrared spectroscopy for measuring internal properties of kiwifruit (Actinidia chinensis). Postharvest Biology and Tech., : 175 - 184.

\section{Throop, J.A., D.J. Aneshansley, W.C. Anger, and D.L. Peterson.} (2005). Quality evaluation of apples based on surface defects: development of an automated inspection system. Postharvest Biology and Tech., 36:281-290.

Toth, D. and T. Aach. (2001). Improved minimum distance classification with Gaussian outlier detection for industrial inspection. In Proc. Int. Conf. Image Analy. and Proc., Palermo : $584-588$.

\section{الملخص العربيى}

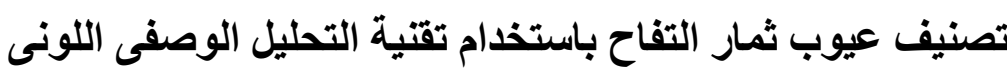

$$
\text { د/ عبدالرحمن عبدالرؤف عبدالرحمن' }
$$

تهدف هذه الدراسة الى استخدام واختبار نظام التحليل اللونى للصور فى تصنيف بعض العيوب

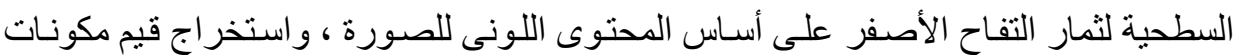

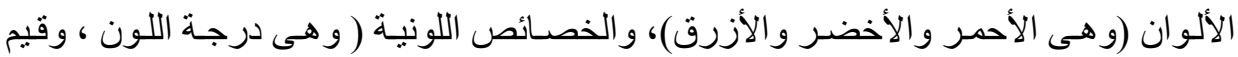

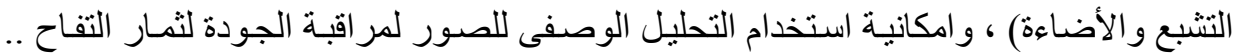

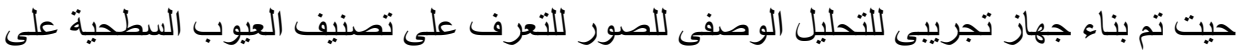

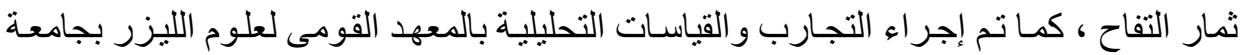

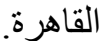
تم اختيار عينات عشو ائية من ثمار التفاح الأصفر من السوق المحلى بمحافظة الجيزة.. حيث تم تجهيز العينات بغسيلها من الأتربة وتجفيفها طبيعيا من آثنار التئهار المياه.

1 - باحث أول بمعهر بحوث الهندسة الزراعية ـ مركز البحوث الزراعية ـ الاقى ـ مصر. 
وتم إعداد هذه العينات للتصويرباستخدام آلتة تصـوير رقميـة ذات حساسية فائقة مـع ثبـات كميـة

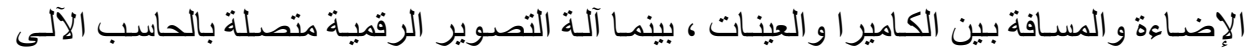

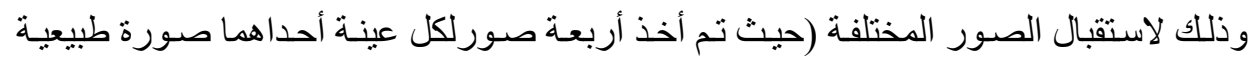

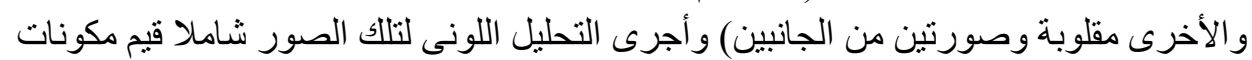

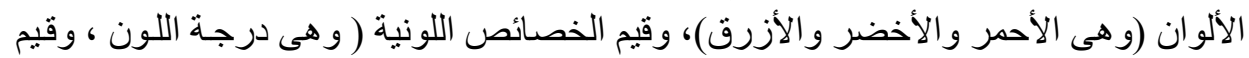

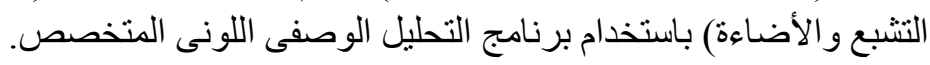

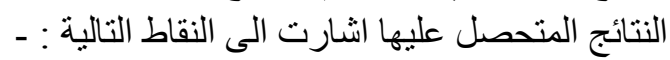

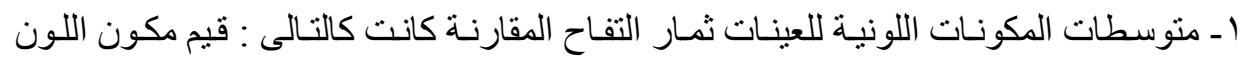

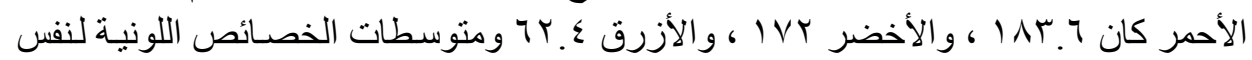

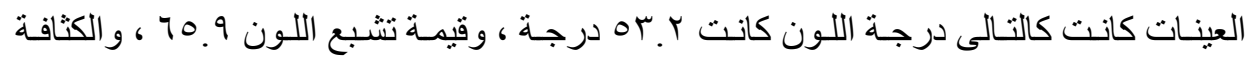

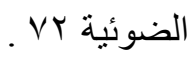

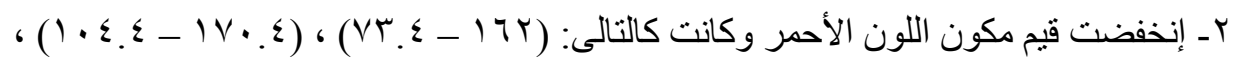

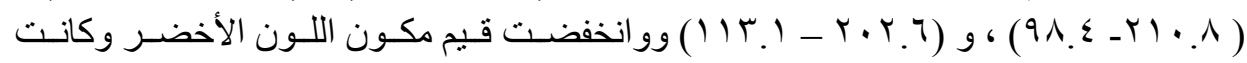

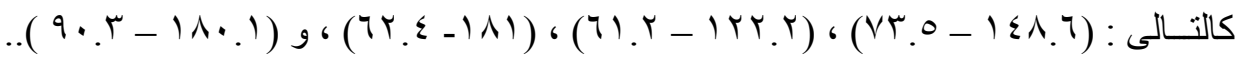

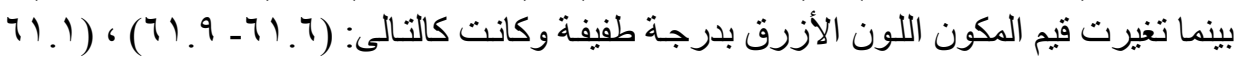

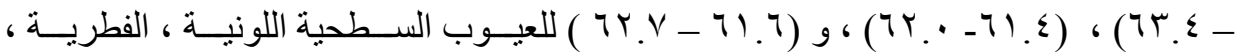

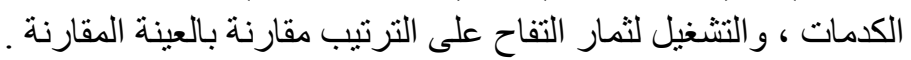

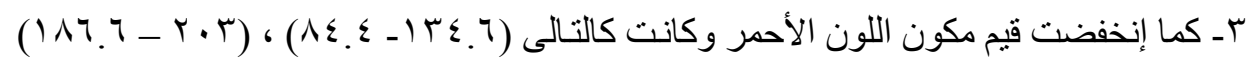

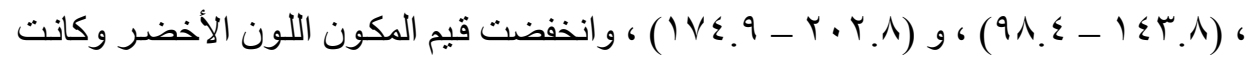

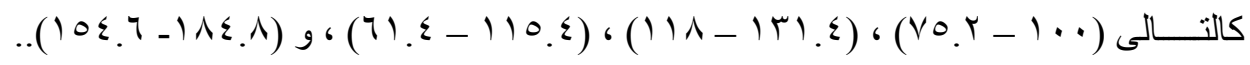

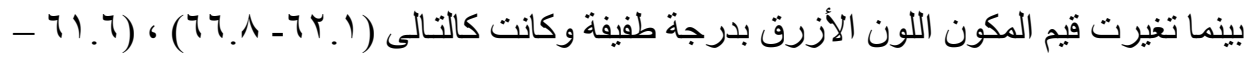

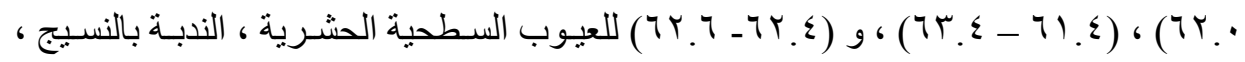
الميكانيكية ، المساحة الضامرة لثمار التفاح على الترتيب ، مقارنة بالعينة المقارنة. عـ تبين ان قيم المكون اللونى (الأحمر ، والأخضر ، و الأزرق) وقيم الخصائص اللونية ( درجـة

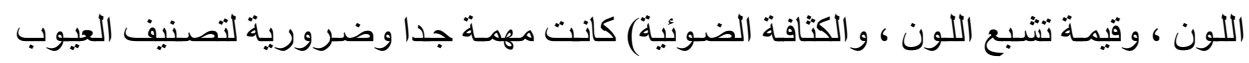
السطحية لثمار التفاح .

هـ تم انثاء مقياس لعيوب ثمار التفاح مقارنة بالعينة السليمة فكانت القيم أقل فى العيوب التالية

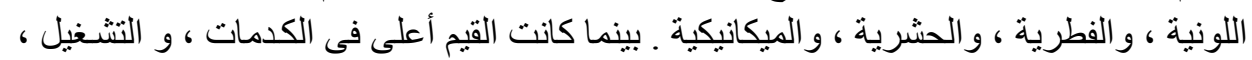
و الندبة بالنسيج ، و و الضامرة.

هـ كمـا تـم اسـتخدام طريـق التحليـل الوصـفى للصـور فـى قيـاس العيوب السـحية لثمار التفـاح وبالتالى فى تطوير نظام الفرز لفرز ثمار التفاح على اساس اللتحليل اللونى.

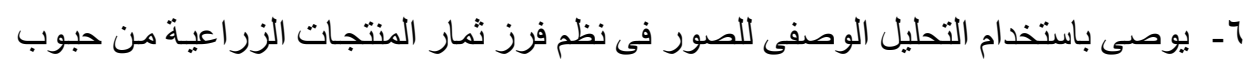
وفاكهة وخضروات فى الأنظمة الآلية. 